\title{
Changes in grass basal area and forb densities over a 64- year period on grassland types of the Jornada Experimental Range
}

ROBERT P. GIBBENS AND RELDON F. BECK

\section{Abstract}

Between 1915 and 1932, permanent $1 \times 1-m$ quadrats were established on grasslands of the Jomada Experimental Range in southern New Mexico. Quadrat records accumulated from 1915 to 1979 on grasslands dominated by black grama [Bouteloua eriopoda (Torr.) Torr.] poverty threeawn (Aristida divaricata Willd.), tobosa [Hilaria mutica (Buckl.) Benth.] and burrograss (Scleropogon brevifollus Phill.) were used to examine changes in perennial grass basal area and forb deneities. Quadrats originally dominated by black grama had large reductions in basal area during droughts, and basal area increased slowly following droughts. By 1979, black grama no longer occurred on $77 \%$ of the quadrats. Quadrats originally dominated by poverty threeawn changed to a mesquite (Prosopis glandulosa Torr. var. glandulosa) type. Perennial grass basal area on quadrats dominated by tobosa and burrograss decreased during droughts, but recovery was relatively rapid. Antecedent precipitation was associated with only 10 to $38 \%$ of the variation in perennial grass basal area. Perennial forb densities were low and fluctuated among years in all types. Annual forbs and grasses displayed large fluctuations in densities among years. The necessity of basing management of Chibuahuan Desert ranges on the perennial grass component is borne out by the low densities of palatable perennial forbs, and the extreme fluctuation and unpredictability in densities of annual forbs and grasses.

Key Words: black grama, poverty threeawn, tobosa, burrograss, arid rangeland

Striking changes have occurred in former grasslands of the northern Chihuahuan Desert. The most obvious and best documented change has been the widespread encroachment of shrubs into former grassland areas (Buffington and Herbel 1965, York and Dick-Peddie 1969). Few areas remain that can be classified as grassland, and Küchler's (1964) classification as shrub-steppe is appropriate for most rangelands of the region. The original grassland types still occur but have been reduced in area, and dominance is often shared with shrubs.

Permanent quadrats, charted on a yearly basis, were once widely used to follow vegetation dynamics in grasslands (Weaver and Albertson 1944, Albertson and Tomanek 1965). Beginning in 1915, permanent quadrats were established on the Jornada Experimental Range in southern New Mexico. Data from these quadrats were the base for evaluating vegetation changes caused by grazing and climatic fluctuations (Nelson 1934, Paulsen and Ares 1962). These quadrat data also furnished a base for determining demographic characteristics of grasses (Wright and Van Dyne 1976, 1981; Gross 1984) as well as other species (Dittberner 1971).

The purpose of this study was to examine changes in grass basal area and forb numbers that have occurred in 4 grassland types during a 64-year period, 1915 to 1979.

\section{Materials and Methods}

This study was conducted on the Jornada Experimental Range

\footnotetext{
Authors are range scientist, Jornada Experimental Range, USDA, Agricultural Research Service, Las Cruces, New Mexico; and professor, Animal and Range Sciences Department, New Mexico State University, Las Cruces.

Published as journal article 1307, Agricultural Experiment Station, New Mexico State University, Las Cruces.

Manuscript accepted 2 December 1987.
}

$37 \mathrm{~km}$ north of Las Cruces, New Mexico. The 78,266-ha Experimental Range lies principally on undulating plains of the closed Jornada basin. Average elevation of the plains is near $1,260 \mathrm{~m}$. On the east, the Experimental Range extends to the crest $(2,833 \mathrm{~m})$ of the San Andres mountains. Mean monthly maximum temperatures are highest in June $\left(36^{\circ} \mathrm{C}\right)$ and lowest in January $\left(13^{\circ} \mathrm{C}\right)$. Long-term average annual precipitation is $230 \mathrm{~mm}$ with $52 \%$ occurring in July, August, and September. Summer precipitation is mostly from high intensity, short duration, convective storms covering small areas. Winter precipitation comes from low intensity frontal storms covering broad areas. Snow is infrequent. The frost-free period averages $\mathbf{2 0 0}$ days, but the effective growing season, when soil water and temperature are favorable, is often 90 days or less.

The Jornada Experimental Range was established in 1912 and placed under the administration of the Bureau of Plant Industry. In 1915 it was transferred to the U.S. Forest Service and has been operated by the Agricultural Research Service since 1954 (Ares 1974). In 1915, 34 permanently marked, $1 \times 1-m$ quadrats were established and charted. Additional quadrats (including only those where markers still exist) were established in 1916 (8), 1919 (14), 1921 (3), $1924(2), 1926(17), 1929$ (2), 1931 (1), and 1932 (2), total (104). A decimeter grid was used to chart the quadrats until 1925 and a pantograph was used thereafter (Campbell 1931). Grass basal area was determined by counting squares (equivalent to $1 / 10,000 \mathrm{~m}$ ) on the grid paper used in charting or, in later years, with a planimeter. With few exceptions, all quadrats were charted each year until 1947 . After 1947 , only a portion of the quadrats were charted each year, resulting in discontinuous records for individual quadrats. Charting was discontinued in 1979.

Besides grass basal area, species and numbers of forbs present on the quadrats were recorded. The forb density data must be viewed with caution because the quadrats were usually sampled in September, October, November, or even December, when probably some forbs had dehised, or palatable forbs had been bitten off by livestock, rabbits, or rodents. It was possible to determine the total number of species recorded for each quadrat sampling because notations like "unidentified perennial forb $A$ " were used for unidentified species. In the 64 years, there were only 168 individuals for which no designation as to annual or perennial forb was given. These were not included in density calculations. We believe the forb numbers were determined with enough precision to allow relative comparisons among years and grassland types.

Quadrat locations were carefully selected to represent average species composition in the major grassland types and were usually placed at $0.8-\mathrm{km}$ intervals along lines radiating from permanent watering points (Nelson 1934). Quadrats were placed on grasslands dominated by black grama [Bouteloua eriopoda (Torr.) Torr.] (57 quadrats), tobosa [Hilaria mutica (Buckl.) Benth.] (22 quadrats), burrograss (Scleropogon brevifolius Phil.) (12 quadrats), poverty threeawn (Aristida divaricata Willd.) (6 quadrats), and blue grama [Bouteloua gracilis (H.B.K.) Griffiths] (6 quadrats). A single quadrat was on a gypsiferous area dominated by gypgrass (Sporobolus nealleyi Vasey). Because the quadrats in the blue grama type and the gypgrass quadrat were charted infrequently after 1947 , they will 
not be discussed. Quadrats representing the black grama and poverty threeawn types are located primarily on shallow $(30 \mathrm{~cm})$ sandy loams (Simona series) underlain by an indurated caliche layer or on deep (to $152 \mathrm{~cm}$ ) loamy sands (Wink and Onite series). The tobosa type is found primarily on deep $>152 \mathrm{~cm}$ ) clay loams (Reagan series), and the burrograss type on deep, fine sandy loams (Dona Ana series) (Bullock and Neher 1980).

Precipitation records are from the centrally located Experimental Range Headquarters. Precipitation is reported on a crop year basis, i.e., crop year precipitation for 1916 is from 1 Oct. 1915 to 30 Sep. 1916. Correlation and regression techniques were used to examine relationships between precipitation and grass basal area and forb numbers. Regressions with precipitation were done on an accumulative basis with a separate regression performed for each accumulation, e.g., grass basal area in a given year was examined in relation to precipitation in September of that year, then with September plus August precipitation, then with September plus August plus July precipitation, etc., until 48 preceding months of precipitation were added. Only those regression coefficients associated with the maximum coefficient of determination $\left(R^{2}\right)$ were tested for significance $(P<0.05)$.

Plant nomenclature follows Correll and Johnston (1970).

\section{Results and Discussion}

\section{Black Grama Type}

The early quadrat records (1915-1925) show a relatively low black grama basal area (Fig. 1). Contemporaneous reports (e.g., Jardine and Forsling 1922, Nelson 1934) attribute the low basal area to unfavorable rainfall patterns. Also, it is likely that livestock grazing, which was proper according to the concepts of the times but would be rated as heavy today, contributed to the relatively low basal area. An early grazing strategy on the Experimental Range was to reduce grazing of the black grama type during the growing season (July-September) and reserve the forage for the dry spring months (March-June) (Jardine and Hurtt 1917).

During the 1926 to 1934 period, there was a large increase in black grama basal area, reflecting relatively more favorable rainfall patterns (Fig. 1). However, the severe drought of 1934 resulted in a sharp decrease in black grama basal area. Canfield (1939) found no new growth in 1934 on any of the black grama quadrats he was studying on the Experimental Range. By 1935 average basal area of black grama on the 57 quadrats was only $3.1 \%$, compared to the high of $9.6 \%$ attained in 1932. Paulsen and Ares (1962) found black grama basal area was reduced to about the same level during dry years, irrespective of grazing intensity or amount of antecedent basal area. Black grama and other perennial grasses partially recovered from the 1934 drought by 1936 , and basal area was relatively stable until 1947. Another severe drought occurred in 1948 and again perennial grass basal area was sharply reduced (Fig. 1). Relatively high rainfall in 1949 and 1950 resulted in a small increase in basal area, but the severe drought of the 1950 s reduced perennial grass basal area to very low levels. The drought of the 1950 s is believed to be the most severe in the Southwest in the past 350 years (McDonald 1956, Schulman 1956). Herbel et al. (1972) found the reduction in black grama during the 1950s was greatest on deeper soils and least on shallow soils underlain with impervious caliche layers. They hypothesized the caliche layer prevented deep percolation, holding water within reach of plant roots.
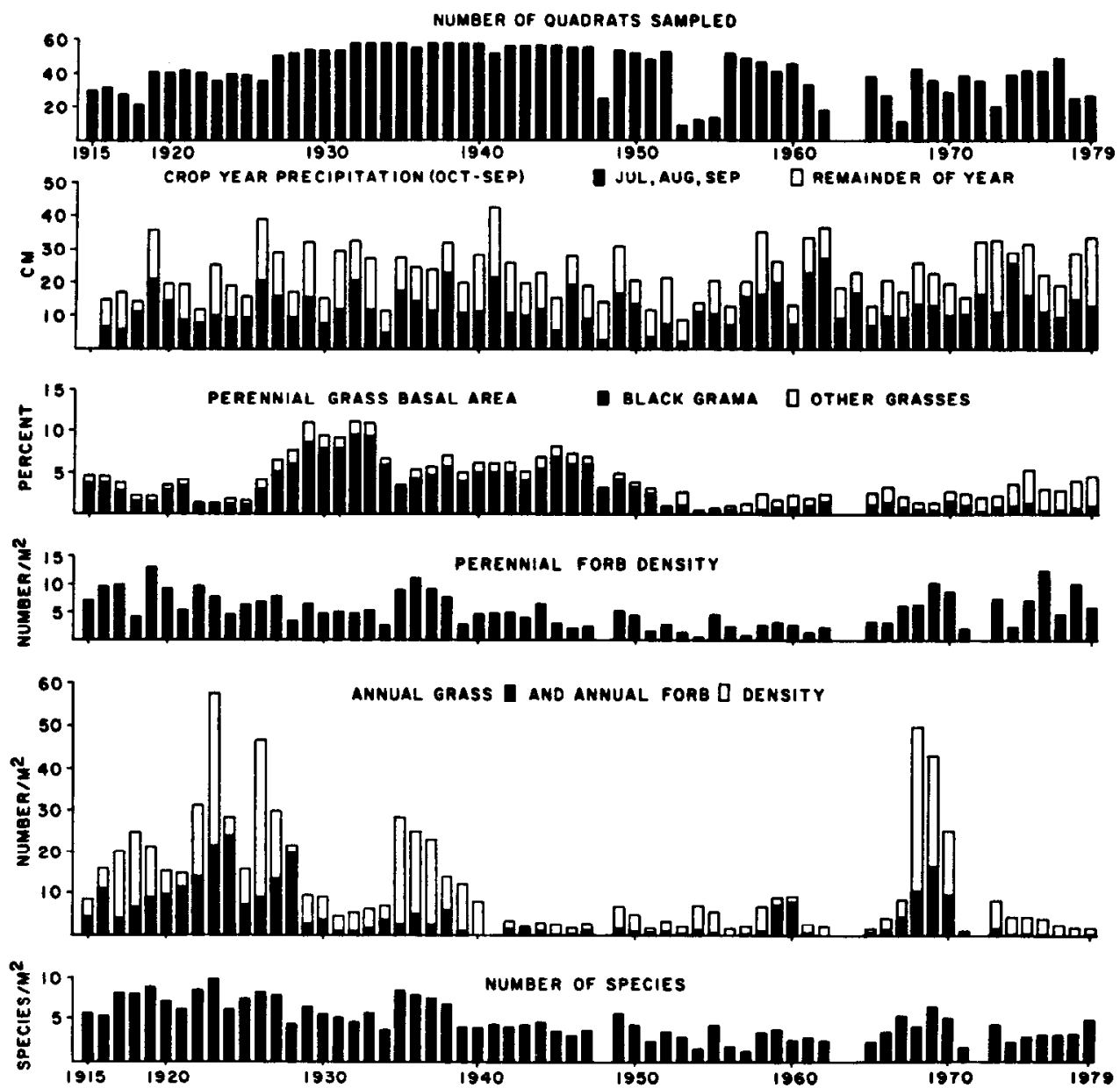

Fig. 1. Number of quadrats sampled, crop-year precipitation, perennial grass basal area, perennial and annual plant densities, and number of species for the black grame type. Forbs were not counted in 1948 and 1972. 
Following the drought of the 1950 s black grama basal area did not increase to former levels. Also, the proportion of basal area contributed by other perennial grasses increased (Fig. 1). The areas around the 57 quadrats were vegetated by a population of black grama plants originally; however, by 1979 there was a large decrease in areas with black grama. Black grama disappeared from 1 quadrat in each of the following years: 1934, 1935, 1939, 1942, 1944 , and 1946. Following the dry 1948 season, black grama was lost from 3 more quadrats by 1950 . During the severe drought of 1951-56 black grama disappeared from 26 quadrats and by 1961 did not occur on 9 additional quadrats. Thus, black grama no longer occurs on 44 quadrats, or $77 \%$ of the original sites. By 1981 , shrubs were dominant on $24(42 \%)$ of the quadrat sites (Gibbens and Beck 1987).

There was a small subset (6) of quadrats, established in 1915, where black grama persisted for 64 years. Black grama basal area on this subset of quadrats is similar to that portrayed in Figure 1. Average black grama basal area on the 6 quadrats was $4.0 \%$ in 1915. Basal area decreased during the 1920 s but then increased to a high of $14.2 \%$ in 1932 . Following the drought of 1934, basal area decreased to $5.9 \%$ in 1936 , then increased to $10.4 \%$ by 1945 . Black grama basal area was $2.1 \%$ in $1956,6.0 \%$ in 1965 , and $3.0 \%$ in 1977 , the last year all 6 of the quadrats were sampled. Thus, a population of quadrats continuously occupied by black grama shows basal area changes reflecting climatic patterns. The widely separated quadrats have no readily apparent common factor to account for the survival of black grama.

Regression of total perennial grass basal area upon preceding accumulated precipitation revealed a maximum $R^{2}$ of 0.26 at 44 months, and the regression coefficient was significant $(P<0.001)$. The low $R^{2}$ means that accumulated precipitation is not a good predictor of basal area, but is associated with $26 \%$ of the variation in basal area. Log transformations of data did not improve correlations of basal area and precipitation. Also, no improvement was found when only the subset of quadrats in which black grama persisted was examined. One reason for the low correlations with precipitation is the variability in basal area response within a given year. For example, in 1931 there were increases in black grama basal area on 24 quadrats and decreases in basal area on 26 quadrats. Between 1916 and 1950 there were only 2 years, 1928 and 1948 , when all quadrats showed a consistent response (decrease) in black grama basal area.

Seven quadrats were established within livestock exclosures on the black grama type. Clipping studies have shown black grama is sensitive to degree and timing of defoliation, and basal area and reproductive potential (stolon and stoloniferous culm production) can be adversely affected by high rates of defoliation (Canfield 1939, Miller and Donart 1979). However, long-term changes in perennial grass basal area on the 7 protected quadrats were similar to those on quadrats that were grazed.

Neilson (1986), taking into account global climate patterns, analyzed long-term monthly weather records from Las Cruces, N.M. He hypothesized that the pristine black grama grasslands were established under and adapted to "little ice age" type climate and are only marginally adapted to the present, warmer climate. He contends that, with variable but consistent summer rains, the pattern of winter precipitation becomes critical in establishment of perennial life forms with warm-season (usually $C_{4}$ ) grasses favored
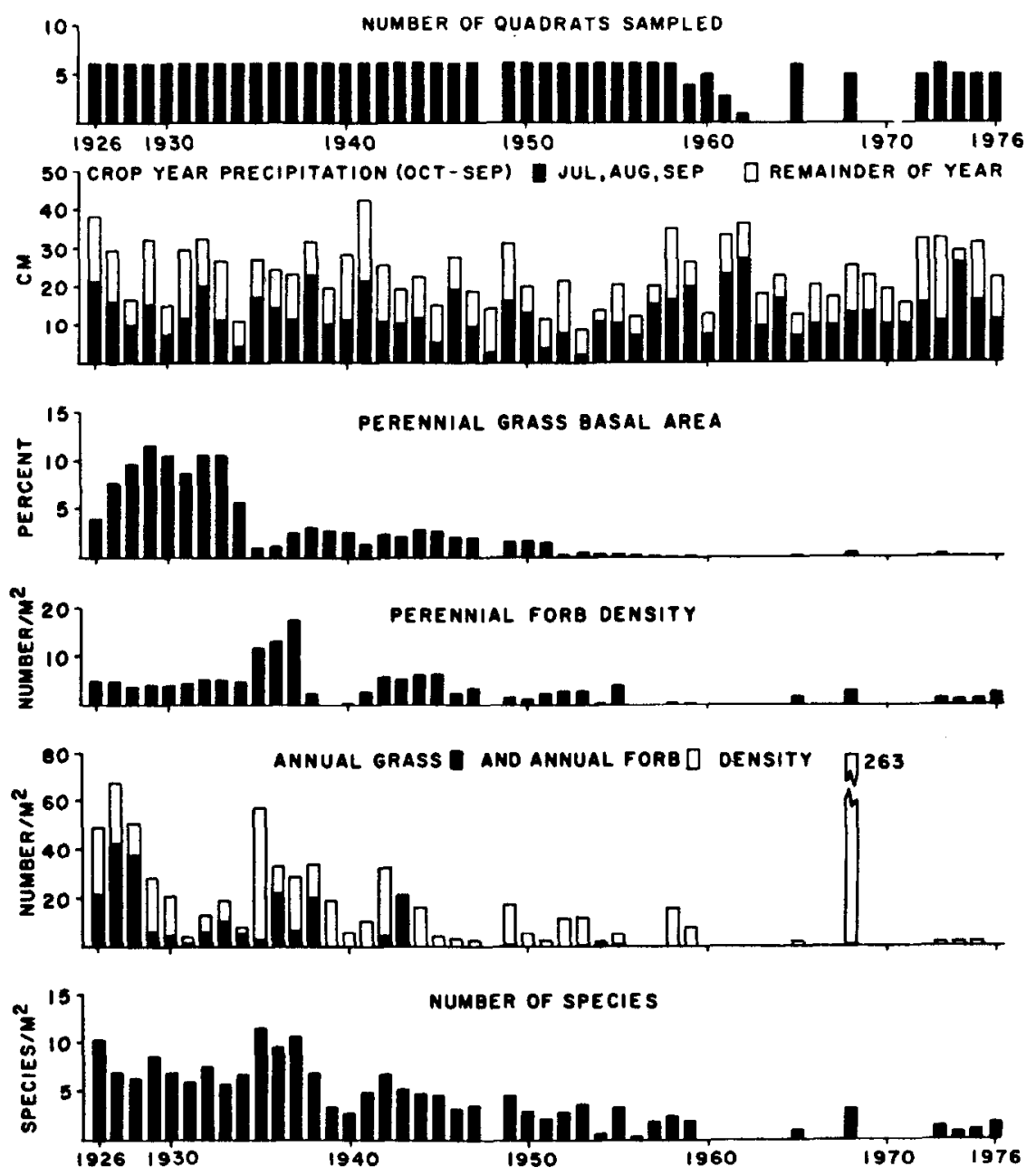

Fig. 2. Number of quadrats sampled, crop-year precipitation, perennial grass basal area, perennial and annual plant densities, and number of species for the poverty threeawn type. Forbs were not counted in 1972. 

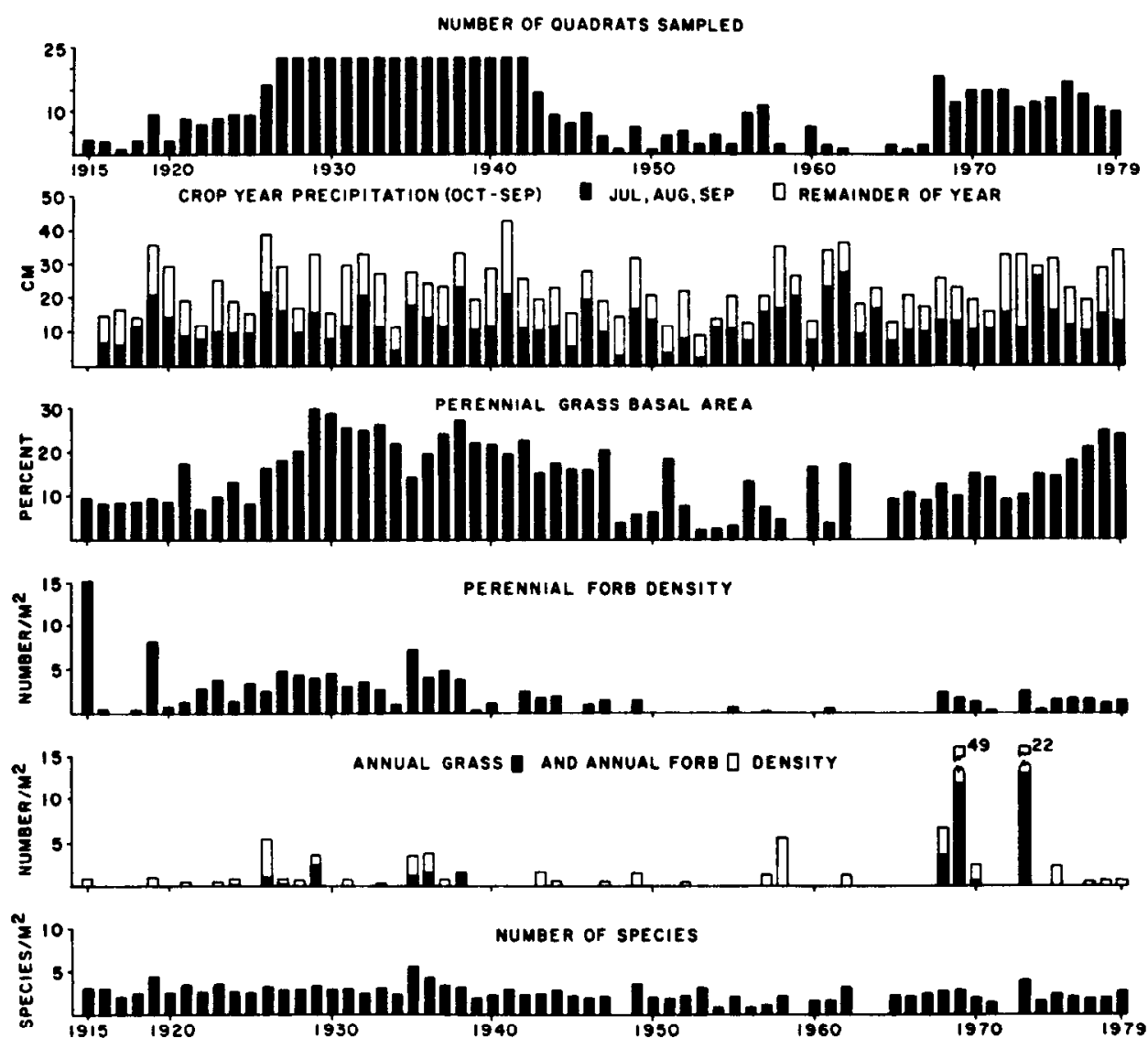

Fig. 3. Number of quadrats sampled, crop-year precipitation, perennial grass basal area, perennial and annual plant densities, and number of species for the tobosa type. Forbs were not counted in 1948 and 1972.

if winters are dry and cool-season (usually $\mathrm{C}_{3}$ ) shrubs favored if winters are wet. He found periods of persistent interannual winter rainfall in the 1930 s and following 1940 which coincided with periods of shrub establishment. Neilson's hypothesis is plausible and the quadrat records show that sexual reproduction (seedlings) of black grama is rare.

Perennial forb density fluctuated during the 64-year period but, unlike black grama basal area, the density of perennial forbs appeared to return to former levels following the drought of the 1950s. The same species of perennial forbs were encountered throughout the 64-year period. The species that were most frequent (based on all quadrat samplings) and most abundant (total number of individuals recorded) were the suffrutescent broom snakeweed [Xanthocephalum sarothrae (Pursh) Shinners], leatherweed croton [Croton pottsii (K1.) Muell. var. pottsii], silverleaf nightshade (Solanum elaeagnifolium Cav.), two-leaved senna (Cassia bauhinioides Gray), trailing allionia (Allionia incarnata L.), and woolly paperflower [Psilostrophe tagetina (Nutt.) Greene].

The density of annual grasses and forbs was extremely variable among years (Fig. 1). Both annual grasses and annual forbs were characterized by years of low density and by years of what might be termed superabundance. Annual forbs were superabundant in $1924,1927,1936,1937,1938,1968,1969$, and 1970. Annual grasses were most abundant in 1924, 1925, 1929, and 1969. Because amount and timing of rainfall are critical in the development of annual plant populations (Went 1948, 1949; Beatley 1974; Kemp 1983), one can expect little correlation between annual plant density and yearly precipitation amounts. Also, different species were most abundant in different years of superabundance, indicating a relatively wide range in optimum conditions for the various species. The most frequent and abundant annual grasses were sixweeks grama (Bouteloua barbata Lag.), needle grama [Bouteloua aristidoides (H.B.K.) Griseb.], and sixweeks threeawn (Aristida adscensionis L.). The most frequent and abundant annual forbs included lemon weed (Pectis spp.), dwarfpea (Astragalus nuttallianus A. DC.), purple rollleaf (Nama hispidum Gray), Russian thistle (Salsola kali L.), annual purslanes (Portulaca spp.), wooly tidestromia [Tidestromia lanuginosa (Nutt.) Standl.], and annual buckwheats (Eriogonum spp.).

Species richness (average number of species per quadrat) was highest in those years when annual plants were most abundant (Fig. 1). Species richness was lower during drought years. Species richness appeared to decrease during the 64-year period, but the discontinuous sampling of quadrats during the 1960 s and 1970 s makes verification impossible.

There were no significant regression coefficients for annual forb numbers and accumulated preceding precipitation. A significant regression coefficient $(P<0.05)$ occurred between perennial forb numbers and 14 months of accumulated precipitation. However, the $\boldsymbol{R}^{2}$ of 0.08 means a small percentage of the fluctuation in perennial forb numbers is associated with accumulated preceding precipitation.

\section{Poverty Threeawn Type}

Six quadrats (Fig. 2) were established in the poverty threeawn type in 1926, one of which was protected from livestock grazing. Small amounts of black grama occurred on 4 of the 6 quadrats. Threeawns are generally considered as secondary species in the 
black grama type (Paulsen and Ares 1962), but can be dominant on small areas.

Total perennial grass basal area increased to a high of $10.6 \%$ in 1932 (Fig. 2). The drought of 1934 caused a sharp reduction in basal area, which was only $1.0 \%$ in 1935 . Although there was some increase in basal area after 1936, the dry 1948 season and the drought of the $1950 \mathrm{~s}$ caused perennial grass basal area to decrease to less than $1.0 \%$. No poverty threeawn occurred on the quadrats after 1952 and no black grama after 1958. The small amounts of perennial grass basal area present in the 1960 s and 1970s were contributed by mesa dropseed [Sporobolus flexuosus (Thurb.) Rydb.] and fluff grass [Erioneuron pulchellum (H.B.K.) Tateoka]. Besides droughts, a primary cause of the decrease in perennial grass area was the invasion of mesquite (Prosopis glandulosa Torr. var. glandulosa) and the formation of mesquite dunes, which now dominate the area where the quadrats are located, including the quadrat site protected from livestock. Norris (1950) concluded from exclusion studies that rabbits and rodents, or even rodents alone, exert enough grazing pressure in mesquite dominated areas to prevent improvement in cover of grasses and forbs.

Regression of total perennial grass basal area upon preceding accumulated rainfall showed a maximum $R^{2}(0.10)$ at 48 months, and the regression coefficient was significant $(P<0.05)$. Separate regressions were calculated using only data from the years 1926-1947, when records were most complete, but there was no improvement in $R^{2}$ values.

There was little variation in perennial forb density from 1926 to 1934 , with density ranging from 3.8 to 5.1 individuals per quadrat. Coincidental with the sharp decrease in grass basal cover in 1935, perennial forb density increased to a high of 17.7 individuals per $\mathrm{m}^{2}$ in 1937 (Fig. 2). However, perennial forb density decreased sharply in 1938 and no forbs were recorded in 1939 . In the early 1940 s perennial forbs reached densities equal to those of the 1920 s but the drought of the 1950s reduced densities to low levels, and records from the late 1970s indicate densities have remained low. The most frequent and abundant perennial forbs included rushpeas (Hoffmanseggia spp.), broom snakeweed and euphorbias (Euphorbia spp.).

Numbers of annual grasses and forbs fluctuated widely among years, even when perennial grass basal area was high (Fig. 2). Annual grasses were particularly abundant in 1927 and 1928 , while annual forbs reached superabundance levels in 1935 and 1968 . The most frequent and abundant annual grasses were sixweeks grama, needle grama and sixweeks threeawn. Annual forbs with high frequency and abundance included purslanes, purple rolleaf, desert baileya (Baileya multiradiata Harv. \& Gray), threadstem carpet-weed [Mollugo cerviana (L.) Ser.], and buckwheats.

There was a definite decline in species richness from 1926 to 1979 (Fig. 2). This reflects the decline in numbers of both annuals and perennials, and indicates that the establishment of mesquite and the formation of dunes resulted in a depauperate flora. It is quite likely rodents, which are more abundant in the mesquite dune type than any other type on the Jornada plain (Wood 1969), contributed to the decline in number of species.

There were no significant relationships between accumulated precipitation and either annual or perennial forb numbers.

\section{Tobosa Type}

The tobosa type usually occurs on heavy soils in low-lying areas that receive some run-in water from overland flows (Herbel and Giles 1973). Five of the 22 quadrats in the tobosa type were on sites where tobosa was the only perennial grass. On the other quadrats, burrograss, ear muhly (Muhlenbergia arenacea Buckl.), alkali sacaton [Sporobolus airoides (Torr.) Torr.], and vine mesquite (Panicum obtusum H.B.K.) were found with tobosa, either singly or in various combinations. One of the quadrat sites was within a livestock exclosure. Only 3 quadrats were established in the tobosa type in 1915. These had a perennial grass basal area of $9.2 \%$ (Fig. 3). By 1927, when all 22 quadrats in the type had been established, perennial grass basal area was $19.2 \%$. Basal area increased to $30.0 \%$ by 1929 , but decreased thereafter. A sharp decrease in basal area occurred in 1935, following the drought of 1934. By 1938 basal area had returned to predrought levels, but declined somewhat in subsequent years. It is difficult to judge the effect of the drought of the 1950 s from the average basal areas shown in Figure 3 because basal area appears to be a function of which of the original 22 quadrats were sampled in any 1 year. Also, which quadrats received run-in water in any given year is not known. However, using one particular quadrat as an example, tobosa basal area was $33.7 \%$ in $1929,16.3 \%$ in $1949,8.4 \%$ in 1952 , and $39.0 \%$ in 1960 . In this case at least, the drought of the 1950 s caused a reduction in tobosa basal area but recovery was fairly rapid. Basal area on quadrats sampled in the late 1960 s and $1970 \mathrm{~s}$ indicates a return to amounts of basal area present before the drought of the 1950s. Tobosa remained present on all but 3 of the quadrats and the protected quadrat was one of those from which tobosa disappeared. Shrubs became dominant on 1 quadrat. The quadrat records indicated interpretations of basal area in the tobosa type varied considerably among recorders, and this is believed to contribute to the high variation among years.

Regressions of perennial grass basal area upon accumulated preceding rainfall showed a maximum $R^{2}$ of 0.38 at 43 months. The regression coefficient was significant $(P<0.001)$.

Perennial forb density in the tobosa type was generally low, and particularly so after the 1950 s drought (Fig. 3). The most frequent and abundant forbs included desert holly (Perezia nana Grey), broom snakeweed, euphorbias, and globemallows (Sphaeralcea spp.). With the exception of the years 1969 and 1973, density of annual grasses and forbs was low in the tobosa type (Fig. 3). Russian thistle, portulacas, dwarfpea, and hairy caltrop or carpetweed (Kallstroemia hirsutissima Vail) were the most frequent and abundant annual forbs. Sixweeks grama, sixweeks threeawn, and annual lovegrass (Eragrostis spp.) were the most common annual grasses.

Species richness was low in the tobosa type and remained fairly constant (Fig. 3). The sod-forming tobosa apparently limits the number of species that can coexist.

When forb numbers were regressed upon accumulated precipitation, maximum $R^{2}$ 's occurred at 12 months for both annual $(0.08)$ and perennial forbs $(0.09)$. Regression coefficients were significant $(P<0.05)$.

\section{Burrograss Type}

Like the tobosa type, burrograss normally occurs on heavy soils in low-lying areas (Paulsen and Ares 1962). Few of the 12 quadrats located in the burrograss type were placed on sites where burrograss was the only perennial grass. Associated grasses included early muhly, tobosa, alkali sacaton, and black grama. One quadrat was within a livestock exclosure. Basal area on the 1 to 6 quadrats sampled from 1915 to 1925 was low, not exceeding 6.5\% (Fig. 4). Basal area increased markedly in 1926, a year of high rainfall. Large decreases in basal area occurred in 1934 and 1935 (Fig. 4). By 1938, basal area had increased to pre-drought levels. Basal area was reduced by the drought of the 1950s but was relatively high in comparison to other types throughout the 1950s. Basal area following the 1950s drought varied widely, but high years were equal to or above levels in the 1930s and 1940s (Fig. 4). The stoloniferous habit of burrograss enables this species to spread rapidly in years of favorable rainfall (Campbell 1931). Burrograss remained present on all but 2 of the quadrat sites. Basal cover on the quadrat protected from grazing was similar to that of grazed quadrats. Shrubs became dominant on 1 quadrat.

Regression of basal area upon accumulated precipitation revealed a maximum $R^{2}(0.38)$ at 41 months. The regression coefficient was significant $(P<0.001)$. As in the other grassland types, more of the variation in basal area is associated with precipitation, if rainfall from the preceding 3-4 year period is considered.

There was a great deal of variation in perennial forb density with 

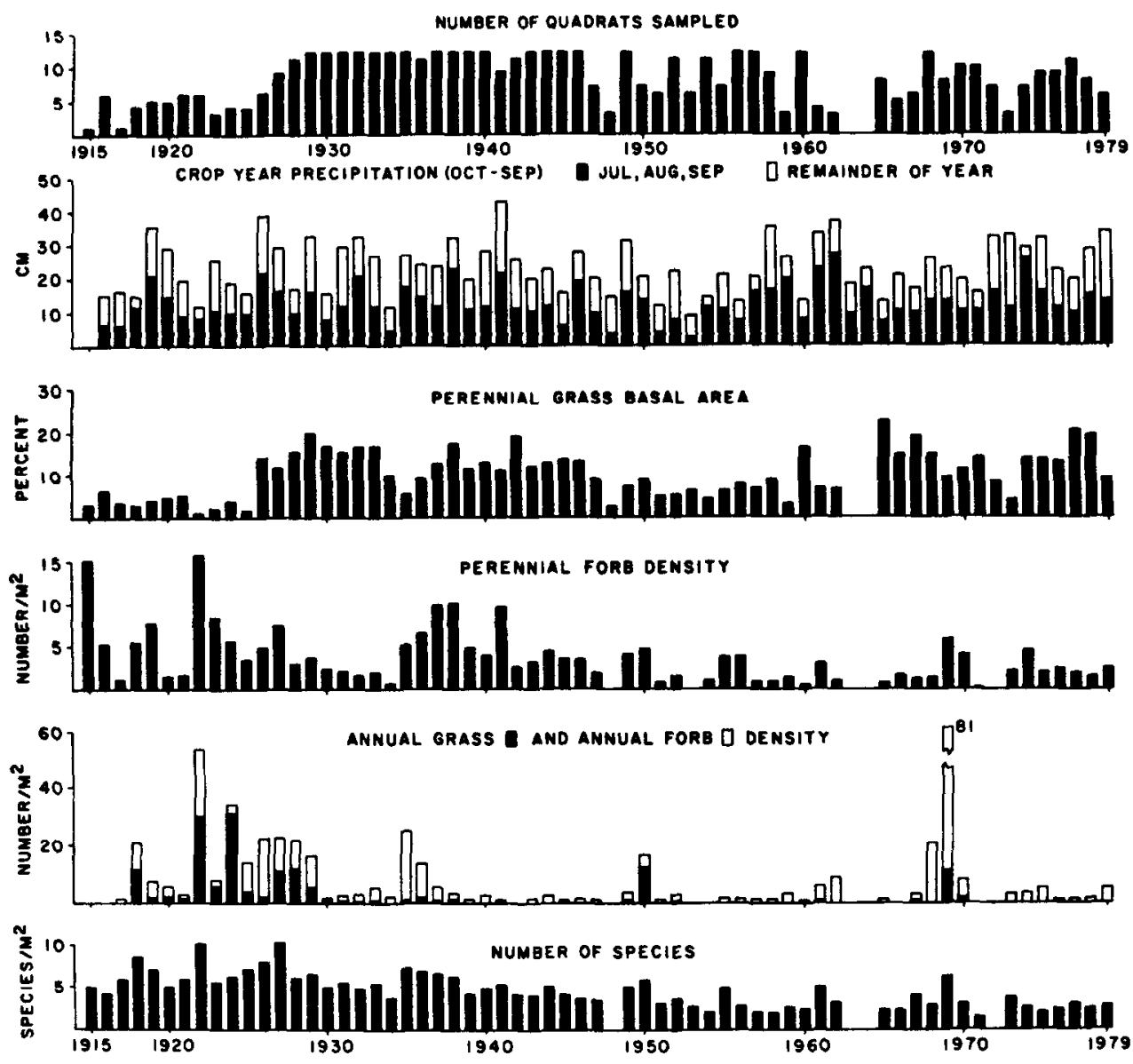

Fig. 4. Number of quadrats sampled, crop-year precipilation, perennial grass basal area, perennial and annual plant densities, and number of species for the burrograss type. Forbs were not counted in 1948 and 1972.

no clear correlation with either precipitation or perennial grass basal area (Fig. 4). The most frequent and abundant perennial forbs were Fendler bladderpod [Lesquerella fendleri (Gray) Wats.], leatherweed croton, broom snakeweed, and rushpeas. In most years, the number of annual grasses and forbs was low (Fig. 4). A notable exception was 1922, a year of low rainfall, when both annual grasses and forbs were exceptionally abundant. Also, 1969 had a superabundance of annuals. Mouseear, Russian thistle and bitterweed (Hymenoxys odorata DC.) were the most frequent and abundant annual forbs. Sixweeks grama, needle grama and sixweeks threeawn were the most abundant annual grasses.

Species richness was somewhat higher than in the tobosa type (Figs. 3 and 4). This appeared to be due to the greater abundance of annuals in the burrograss type. Species richness appeared to be lower in the 1960s and 1970s than in the 1920s and 1930s.

No significant relationships were found between annual and perennial forb numbers and accumulated precipitation. This was also true when the pre-1947 data set was examined separately.

\section{Conclusions}

These long-term quadrat records, accumulated at great expense, suffer from small sample size, a defect which was intensified by erratic sampling. However, the sheer length of the records allows some conclusions to be drawn. Perennial grass basal area is associated to some degree with 3 to 4 years of antecedent precipitation. The relationship between precipitation and perennial grass basal area is not strong because we do not have measured inputs at each quadrat site and because of our inability to define what is effective precipitation. Long-term, detailed studies of vegetation in desert areas receiving a high percentage of precipitation from localized, convectional storms should not be undertaken unless precipitation can be measured at each sampling site.

The few quadrats protected from grazing indicate that grazing has not had a significant impact upon perennial grass basal area. Drought years appear to have a tremendous influence upon perennial grass basal area and upon the composition of contributing grasses, particularly in the black grama type. The vulnerability of black grama to drought, and its relatively slow recovery, must be borne in mind when formulating grazing management plans. In contrast, tobosa and burrograss types offer a forage source less susceptible to drought and with relatively rapid recovery rates. The necessity of basing management of Chihuahuan Desert ranges on the perennial grass component is borne out by the low densities of perennial forbs and the extreme fluctuation and unpredictability in densities of annual forbs and grasses. The most serious problem is the widespread establishment of unpalatable shrubs which has occurred in spite of enlightened, conservative grazing management.

\section{Literature Cited}

Alberteon, F.W., and G.W. Tomanek. 1965. Vegetation changes during a 30-year period on grassland communities near Hays, Kansas. Ecology 46:714-720.

Ares, F.N. 1974. The Jornada Experimental Range. Soc. for Range Manage. Range Monogr. No. 1.

Beatley, J.C. 1974. Phenological events and their environmental triggers in Mojave Desert ecosystems. Ecology 55:856-863. 
Bumington, L.C., and C.H. Herbel. 1965. Vegetation changes on a semidesert grassland range from 1858 to 1963. Ecol. Monogr. 35:139-164.

Bullock, H.E. Jr., and R.E. Neher. 1980. Soil survey of Dona Ana County area of New Mexico. SCS, USDA in cooperation with BLM and New Mexico Agr. Exp. Sta.

Campbell, R.S. 1931. Plant succession and grazing capacity on clay soils in Southern New Mexico. J. Agr. Res. 43:1027-1051.

Canfield, R.H. 1939. The effect of intensity and frequency of clipping on density and yield of black grama and tobosa grass. USDA Tech. Bull. 681 .

Correll, D.S., and M.C. Johnaton. 1970. Manual of the vascular plants of Texas. Texas Res. Found., Renner, Texas.

Dittberner, P.L. 1971. A demographic study of some semi-desert grassland plants. M.S. Thesis New Mexico State Univ., Las Cruces.

Glbbens, R.P., and R.F. Beck. 1987. Increase in number of dominant plants and dominance-classes on a grassland in the northern Chihuahuan Desert. J. Range Manage. 40:136-139.

Gross, B.D. 1984. Demographic sensitivity of 2 perennial desert grasses [Bouteloua eriopoda (Torr.) Torr. and Sporobolus flexuosus (Thurb.) Rydb.] with inferences toward ecological dominance and subdominance. Ph.D. Diss. New Mexico State Univ., Las Cruces.

Herbel, C.H., F.N. Ares, and R.A. Wright. 1972. Drought effects on a semidesert grassland range. Ecology 53:1084-1093.

Herbel, C.H., and L.H. Gile. 1973. Field moisture regimes and morphology of some arid-land soils in New Mexico. p. 119-152. In: R.R. Bruce, K.W. Flach, and H.M. Taylor (eds.). Field soil water regimes. Soil Sci. Soc. Amer. Spec. Pub. 5. Madison, Wisc.

Jardine, J.T., and Forsling, C.L. 1922. Range and cattle management during drought. USDA Bull. 1031.

Jardine, J.T., and L.C. Hurtt. 1917. Increased cattle production on southwestern ranges. USDA Bull. 588.

Kemp, P.R. 1983. Phenological patterns of Chihuahuan Desert plants in relation to the timing of water availability. J. Ecol. 71:427-436.

Kïchler, A.W. 1964. The potential natural vegetation of the conterminous United States Map. Amer. Geog. Soc. Special Pub. 361.
MeDonald, J.E. 1956. Variability of precipitation in an arid region: A survey of characteristics for Arizona. Tech. Rep. on the meterorology and climatology of arid regions, No. 1 Inst. of Atmos. Phys., Univ. of Arizona, Tucson.

Miller, R.F., and G.B. Donart. 1979. Response of Bouteloua eriopoda (Torr.) Torr. and Sporobolus flexuosus (Thurb.) Rydb. to season of defoliation. J. Range Manage. 32:63-67.

Neilson, R.P. 1986. High-resolution climatic analysis and Southwest biogeography. Science 232:27-34.

Nelson, E.W. 1934. The influence of precipitation and grazing upon black grama grass range. USDA Tech. Bull. 409.

Norris, J.J. 1950. Effect of rodents, rabbits and cattle on 2 vegetation types in semidesert rangeland. New Mexico Agr. Exp. Sta. Bull. 353.

Paulsen, H.A. Jr., and F.N. Ares. 1962. Grazing values and management of black grama and tobosa grasslands and associated shrub ranges of the Southwest. USDA, Forest Service Tech. Bull. 1270.

Schulman, E. 1956. Dendroclimatic changes in semiarid American. Univ. of Arizona Press, Tucson.

Weaver, J.E., and F.W. Albertson. 1944. Nature and degree of recovery of grassland from the great drought of 1933 to 1940 . Ecol Monogr. 14:393-479.

Went, F.W. 1948. Ecology of desert plants. I. Observations on germination in the Joshua Tree National Monument, California. Ecology 29:242-253.

Went, F.W. 1949. Ecology of desert plants. II. The effects of rain and temperature on germination and growth. Ecology 30:1-13.

Wood, J.E. 1969. Rodent populations and their impact on desert rangelands. New Mexico State Univ. Agr. Exp. Sta. Bull. 555.

Wright, R.G., and G.M. Van Dyne. 1976. Environmental factors influencing semidesert grassland perennial grass demography. Southwest. Natur. 21:259-274.

Wright, R.G., and G.M. Van Dyne. 1981. Population age structure and its relationship to the maintenance of a semidesert grassland undergoing invasion by mesquite. Southwest. Natur. 26:13-22.

York, J.C., and W.A. Dick-Peddle. 1969. Vegetation changes in southern New Mexico during the past hundred years. p. 157-166. In: W.G. McGinnies and B.J. Goldman (eds.) Arid lands in perspective. Univ. of Arizona Press, Tucson.

The 3rd International Symposium on Polsonous Plants (formerly called the U.S. Australian Symposium on Poisonous Plants) will be held in Logan, UT, USA, July 23-29, 1989. It will be open to all persons interested in or doing research work on poisonous plants. The symposium will consist of invited symposium speakers and submitted platform or poster presentations. For more information contact the program chairman:

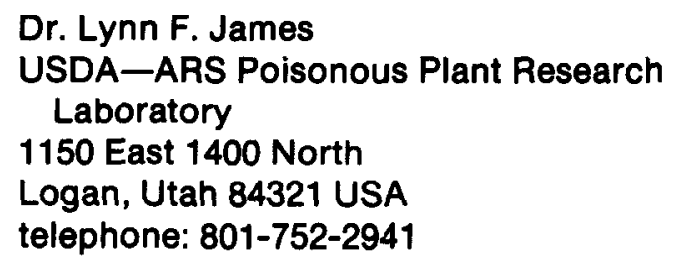

